\title{
PERAN AKTIF ARSITEKTUR DALAM MEMBENTUK POLA PERILAKU MASYARAKAT YANG SADAR LINGKUNGAN MELALUI PERSEPSI RUANG
}

\author{
Chelsea Taurusia Chandra ${ }^{1)}$, Franky Liauw ${ }^{21}$ \\ 1)Program Studi Sarjana Arsitektur, Jurusan Arsitektur dan Perencanaan, Fakultas Teknik, \\ Universitas Tarumanagara, chelseachandra.cc@gmail.com \\ 2) Program Studi Sarjana Arsitektur, Jurusan Arsitektur dan Perencanaan, Fakultas Teknik, \\ Universitas Tarumanagara, frankyl@ft.untar.ac.id
}

Masuk: 02-07-2021, revisi: 10-08-2021, diterima untuk diterbitkan: 23-10-2021

\begin{abstract}
Abstrak
Dalam menjalankan kehidupan, secara sadar ataupun tidak, kerap kali lingkungan menjadi pihak yang dirugikan oleh perilaku manusia. Sedangkan, produk-produk yang dikonsumsi manusia bersumber dari alam. Dalam hal ini, perlu adanya masukkan pemahaman kepada masyarakat untuk semakin sadar akan lingkungan di sekitarnya. Arsitektur, sebagai wadah kegiatan, dapat berperan aktif dalam membentuk karakter masyarakat yang sadar akan lingkungan. Dengan pendekatan empat kuadran AQAL (All Quadrants All Levels) dan model transteoritikal, proyek ini diharapkan dapat menumbuhkan cinta kasih terhadap lingkungan melalui permainan persepsi ruang. Kombinasi karakter setiap kuadran yang menunjukkan sisi psikologis individu diterjemahkan menjadi jenis aktivitas dengan sifat yang mendukung. Aktivitas motorik yang dapat menjadi stimulus interaksi sosial menjadi perantara antarkegiatan. Program proyek dapat diintegrasikan dengan ekstrakurikuler sekolah dasar, menjadi objek penelitian, serta tujuan rekreasi dan bersantai.
\end{abstract}

Kata kunci: arsitektur keperilakuan; kesadaran lingkungan; persepsi ruang

\begin{abstract}
Eventually, whether consciouslly or not, we humans keep ignoring nature and the environment as if they're not more impactable than us. Meanwhile, the products we consumed are mostly made/created from natural sources. In this case, it is necessary to give a proper understanding of nature-aware. Architecture as part of our daily life has an active role in creating a character with environmental consciousness. Approaching AQAL's four quadrants of consciousness and trans-theoretical model expressed in spatial perception, hopefully, this project could develop human's natural consideration on behaving which also affects those around them. Each quadrant's unique psychological character is translated to supporting activities. Some motoric-stimulatic activites provokes social interaction between visitors, which is suitable to be put at open areas. The activities implied can be integrated with schools' extracurricular programs, work as research objects, and refreshment recreational attractions in this crowded city area. This project is targetting primary ages with the hope that they can show a positive character and develop better ones later.
\end{abstract}

Keywords: behavioral architecture; environmental consciousness; spatial perception

\section{PENDAHULUAN}

\section{Latar Belakang}

Ekosistem sebagai hasil dari gabungan unit-unit biosistem melibatkan interaksi di dalamnya. Kelangsungan hubungan timbal balik tersebut bergantung pada perilaku manusia terhadap lingkungan itu sendiri. Kesalahpahaman dan kegagalan manusia dalam memahami hakikat serta realitas alam mengakibatkan reduksi makna 'alam' atau nature menjadi kurang memiliki nilai intrinsik dan spiritual, kecuali nilai yang dilekatkan manusia kepadanya. Terlebih lagi sejak abad 
ke-19, spiritualitas tidak lagi diterapkan pada makna yang berhubungan dengan roh atau fenomena psikis, melainkan pada makna kontemporer. Esensi tersebut menjadikan keragaman refleksi akan realitas spiritualitas semakin luas, sehingga diperlukan penegasan pada konteks ekologis, khususnya yang berkaitan dengan imajinasi ekologi (ecological imaginations). Tony Watling mempertegas dalam 'religious ecotopias' yang menggambarkan imajinasi kepercayaan terhadap alam dan manusia dengan keharmonisan, kearifan, kebersamaan, interpendensi, dan kesakralan (Watling, 2011).

\section{Rumusan Permasalahan}

Berdasarkan latar belakang permasalahan, penulis melirik dua permasalahan utama yang perlu dipelajari lebih lanjut. Masalah pertama ialah mencari metode untuk menyadarkan masyarakat tentang pentingnya menjaga keseimbangan lingkungan melalui pendekatan-pendekatan psikologis sehingga setiap proses dapat berjalan alamiah. Selain itu, arsitektur juga harus berperan aktif bukan hanya sebagai wadah tetapi juga menjadi dampak positif dalam proses penyadaran tersebut.

\section{Tujuan}

Perancangan ini bertujuan untuk membuka persepsi kesadaran masyarakat mengenai pentingnya menjaga keseimbangan alam serta membentuk dan memperbaiki kebiasaan (habit) yang dapat berdampak negatif terhadap lingkungan sekitar.

\section{Manfaat}

Proyek ini diharapkan dapat menjadi sistem aktif pembentuk masyarakat yang lebih bertanggungjawab atas perilaku sehari-harinya, sehingga timbul kesadaran untuk senantiasa menjaga kelestarian lingkungan.

\section{Ruang Lingkup Penulisan}

Penulisan ini berisi tentang perjalanan dalam merumuskan masalah hingga menentukan kriteria aktivitas dan pengguna utama untuk mewujudkan masyarakat yang sadar lingkungan hingga aplikasi teori, ide konsep, dan metode dalam perancangan. Proses tersebut juga disertai dengan beberapa studi proyek terkait yang dapat diambil intisarinya untuk dipelajari lebih lanjut.

\section{KAJIAN LITERATUR}

\section{Ekologi}

Istilah 'ekologi' pertama kali dicetuskan oleh Ernst Haeckel pada tahun 1866 silam (Burnie, 2005). Kata ekologi sendiri berasal dari bahasa Yunani, yaitu: 'oikos' yang berarti habitat dan 'logos' yang berarti ilmu. Dalam ilmu lingkungan, ekologi dijadikan sebagai ilmu dasar untuk memahami interaksi yang terjadi di dalam lingkungan. Secara umum, ekologi merupakan ilmu yang mempelajari tentang hubungan atau interaksi antarorganisme dengan lingkungannya.

\section{Etika Lingkungan}

Etika lingkungan merupakan suatu konsep yang penting untuk dipahami, karena etika lingkungan merupakan kajian baru yang membahas kaitan antara ilmu filsafat dan biologi, khususnya lingkungan (Hudha, 2018). Menurut Velasquez (Velasquez, 2010), etika mengacu pada penetapan standar hak dan kewajiban serta studi dan pengembangan standar etika seseorang. Perasaan, hukum, dan norma sosial dapat menyimpang dari apa yang seharusnya. Hal ini berarti perlu ada pemeriksaan standar secara kontinu terhadap seseorang untuk memastikan bahwa mereka logis dan beralasan. 
Keempat prinsip etika sebagaimana dijelaskan oleh Komisi Bioetika Nasional mengandung makna dan pesan yang dikehendaki untuk diterapkan dalam kehidupan bermasyarakat, antara lain: bertanggungjawab atas pilihannya (autonomy), memastikan tidak ada pihak lain yang dirugikan atas perbuatan kita (non-maleficence), memperhatikan kesejahteraan makhluk dan ciptaan lain (beneficence), serta pembagian manfaat dan beban yang ditentukan oleh prinsip dan bukan kebutuhan (justice).

\section{Teori Integral Kesadaran}

Wilber mengembangkan pendekatan filosofis pada kesadaran, psikologi transpersonal, dan psikologi integral. Teori integral dimaksudkan untuk menyelesaikan sebuah 'masalah' -dalam kasus ini adalah kesadaran- yang dipetakan dalam empat kuadran AQAL (All Quadrants All Levels). Teori ini merupakan bentuk kritik terhadap teori lain yang memecahkan masalah psikologi hanya dari satu aspek, tetapi tidak dapat menutupi aspek yang lain.

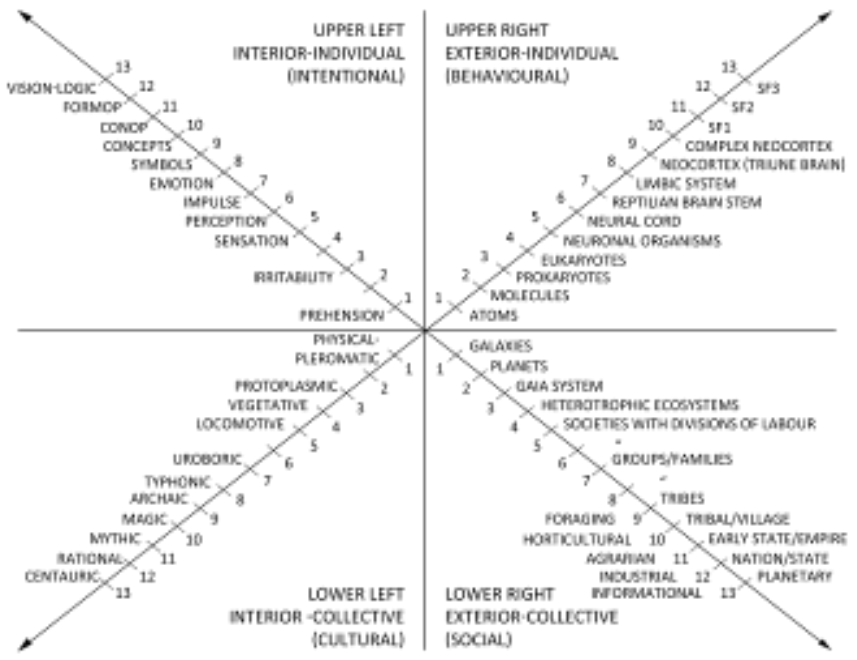

Gambar 1. The Four Quadrants (Prochaska, 1982)

Sumber: Wilber, 1997

Masing-masing kuadran memiliki jenis kebenaran, pengetahuan, bukti, dan prosedur yang berbeda. Sebuah proposisi dapat dikatakan benar jika cocok dengan fakta objektif (kebenaran representasi dan teori korespondensi kebenaran). Kesadaran bukan berasal dari dalam diri seseorang, melainkan menyangkut empat kuadran. Setiap mode pengetahuan dalam teori integral terdiri atas tiga komponen serupa yaitu: perintah, pemahaman, dan konfirmasi. Keempat validity claims mengikuti ketiga untaian tersebut sebagai sebuah proses untuk memperoleh pengetahuan yang valid, objektif, serta dapat diterapkan secara universal.

\section{Model Transteoritikal}

Model terapi integratif menilai kesiapan individu untuk bertindak atas perilaku baru yang lebih sehat, menyediakan strategi, atau proses perubahan untuk memandu individu. Menurut Prochaska (Prochaska, 1982), individu yang telah berhasil membuat perubahan positif dalam hidupnya cenderung melewati 5 tahapan atau fase spesifik, antara lain: pra-kontemplasi, kontemplasi, persiapan, tindakan/perilaku, dan pemeliharaan atau konsistensi dalam mempertahankan tindakan positif tersebut. 

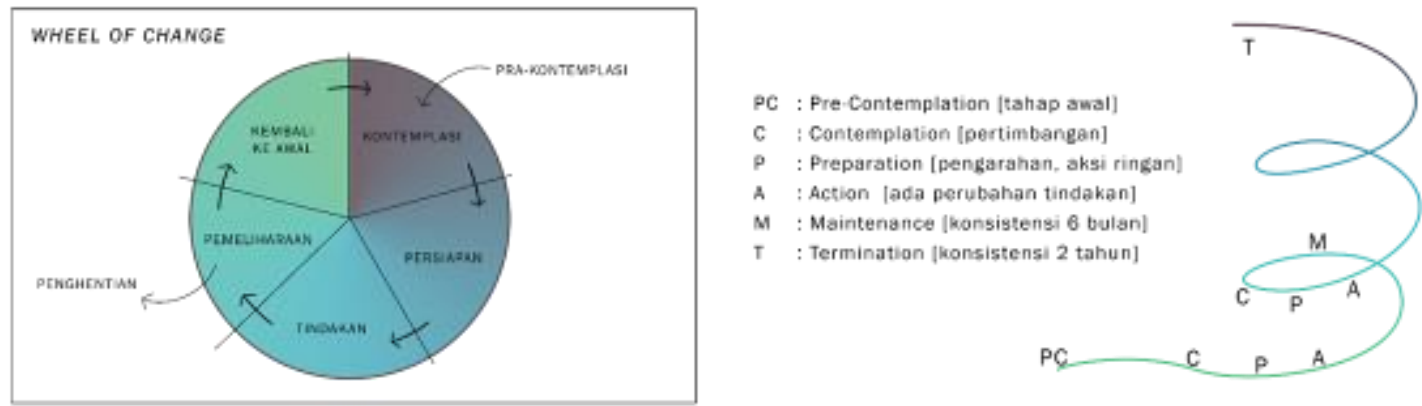

Gambar 2. Wheel of Change \& Prochaska's Spiral

Sumber: Prochaska, DiClemente \& Norcross, 1992

\section{1/90 Rules}

Dr. Maxwell Maltz menyatakan bahwa pola kebiasaan baru perlu dilakukan setiap harinya secara teratur agar menjadi sesuatu yang permanen. Menurutnya, tahap pertama pembentukkan tersebut adalah setelah dilakukan selama 3 minggu secara rutin. Kemudian, kebiasaan rutin tersebut akan menjadi habit yang permanen apabila dapat dilaksanakan selama 90 hari secara konsisten (CapeSpace, n.d.).

\section{Analisis}

Prochaska menyatakan bahwa sebuah perubahan akan menjadi kebiasaan baru apabila telah berlangsung selama 2 tahun lamanya. Apabila dibandingkan dengan teori Maxwell Maltz yang menyatakan bahwa kebiasaan menjadi permanen dalam durasi 6 bulan, artinya ada sebuah katalisator yang dapat diterapkan dalam proses perubahan tersebut.

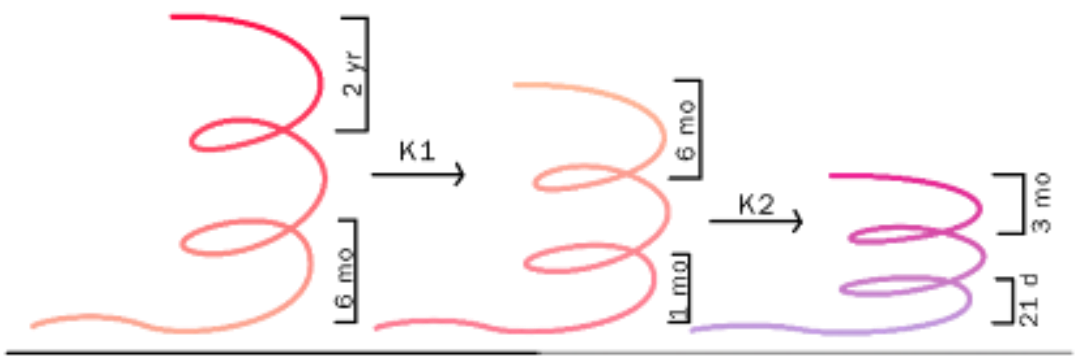

Gambar 3. Pemadatan Durasi Transisional

Sumber: Penulis, 2021

Katalis pada proses ini dapat berupa cara pendekatan atau penerapan baru ke serangkaian aktivitas, sehingga proses adaptasi perubahan membutuhkan durasi yang lebih singkat untuk mendapat hasil yang setara. Percepatan proses ini juga berarti menghadirkan peluang keberhasilan yang lebih tinggi, karena jumlah pengamatan dan sekuen pengalaman yang dialami setiap individu menjadi lebih banyak dan beragam.

Masing-masing kuadran kesadaran memiliki peran penting di dalam proses perubahan. Oleh sebab itu, setiap stimulus atau rangsangan pada salah satu kuadran akan mempengaruhi / berdampak pada proses untuk mempengaruhi kesadaran individu tersebut meski persentasenya tidak besar (Wilber, 1997). 


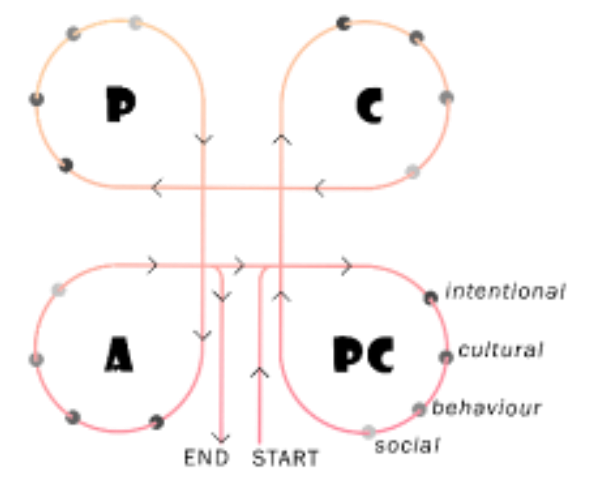

Gambar 4. Skema Kombinasi

Sumber: Penulis, 2021

Oleh sebab itu, injeksi 4 kuadran dalam spiral Prochaska bertujuan untuk setiap proses perubahan dari pra-kontemplasi hingga tindakan sampai saat individu tersebut berada di titik konfirmasi (termination), yaitu ketika ia berhasil meninggalkan pola kebiasaan lamanya.

\section{METODE}

\section{Metode Penulisan}

Metode yang digunakan dalam penulisan ini adalah metode analisis-sintesis, yaitu dengan memilah-milah serta menggabungkan pengertian yang satu dengan yang lain. Dengan cara ini, hasil ilmu gabungan yang diterapkan merupakan kumpulan dari teori-teori yang sudah dianalisis kesesuaiannya dengan materi yang dibahas.

\section{Metode Perancangan}

Proses perancangan diawali dengan studi terhadap permasalahan dan sejumlah teori yang relevan untuk diterjemahkan menjadi bahasa arsitektur dengan menggunakan teori persepsi ruang sesuai dengan tujuan proyek.

Persepsi merupakan salah satu aspek psikologis yang erat kaitannya dengan respon manusia terhadap kondisi di sekitarnya. Ponty mencari hubungan antara subjek dan objek di mana persepsi merupakan bagian dari pemahaman dan keterkaitan manusia dengan dunia (Canas, 2019). Menurutnya, persepsi sebagai sebuah pengorganisasian merupakan komponen yang tersusun atas pola, hubungan, dan kemiripan. Apabila dikaitkan dengan pendapat Plato mengenai perilaku manusia yang terbentuk dari emosi, keinginan, dan pengetahuan, maka akan terbentuk interaksi. Interaksi dalam konteks ekologi terjadi antara makhluk hidup dan lingkungannya tanpa terkecuali dan di dalamnya terdapat emosi yang dapat mempengaruhi sikap pelakunya.

Dengan mengaitkan unsur kemiripan dari Merleau Ponty dengan ekologi, maka terbentuklah kemiripan dengan unsur alam yang dapat dirasakan melalui indera dan meninggalkan memori. Pengembangan persepsi ruang (spatial perception) dicapai dengan stimulus rutin, sehingga disisipkan di setiap kegiatan termasuk ruang luar sebagai area transit. Dengan demikian, setiap pengunjung yang melewati bagian dari perancangan dapat merasakan manfaatnya.

\section{DISKUSI DAN HASIL}

Lokasi Tapak, Program Aktivitas, dan Konsep Perancangan 


\begin{tabular}{|c|c|c|c|c|}
\hline \multirow{2}{*}{ KABUPATEN / MOTA } & \multicolumn{3}{|c|}{ Seketah Desar } & \multirow{2}{*}{$\begin{array}{l}\text { RATA-RAT } \\
\text { UmV } / \mathrm{km} \text { ? }\end{array}$} \\
\hline & $\mathrm{N}$ & 5 & IMI & \\
\hline Total & 1.472 & 1.360 & 2,852 & - \\
\hline Kab, Kea. Seribu $\left(11,81 \mathrm{~km}^{2}\right)$ & 15 & 0 & 15 & 1,27 \\
\hline Kotd Jakarla Pubat $[47.9 \mathrm{~km}$ ) & 182 & 114 & 296 & 6.17 \\
\hline Kuta Jakaria U:sra (142.2 $\mathrm{km}^{7}$ ) & 154 & 288 & 416 & 2.9 \\
\hline Kata Jakarta Barat $\left(126,15 \mathrm{~km}^{3}\right)$ & 363 & 356 & 719 & 5,69 \\
\hline Kota Jakaris Selatan $(145,73 \mathrm{~km}$ '? & 315 & $31\}$ & 632 & 4,3 \\
\hline Kota Jakarta Timur $\left[18 \mathrm{gr}, 73 \mathrm{~km}^{2}\right]$ & 446 & 328 & 774 & 4,13 \\
\hline
\end{tabular}

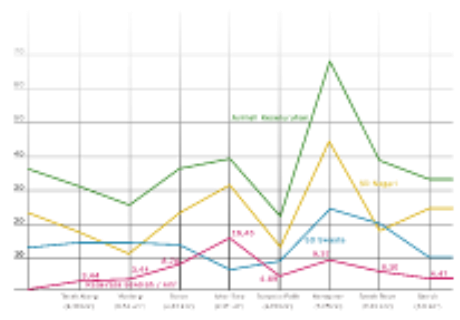

Gambar 5. Jumlah Sekolah Dasar di DKI Jakarta dan Jakarta Pusat Sumber: Data Referensi Kemdikbud

Perancangan menargetkan anak-anak usia 7-11 tahun (rentang usia siswa Sekolah Dasar), di mana rentang usia tersebut merupakan masa seseorang untuk mengembangkan karakternya. Dengan demikian, pencarian tapak mengutamakan wilayah dengan kepadatan Sekolah Dasar (SD) paling tinggi di Provinsi DKI Jakarta. Berdasarkan referensi data Kemdikbud, hasil kepadatan tertinggi ada di Kecamatan Johar Baru (16,45 sekolah/ $\left.\mathrm{km}^{2}\right)$ dengan asumsi setiap sekolah memiliki jumlah murid setara.

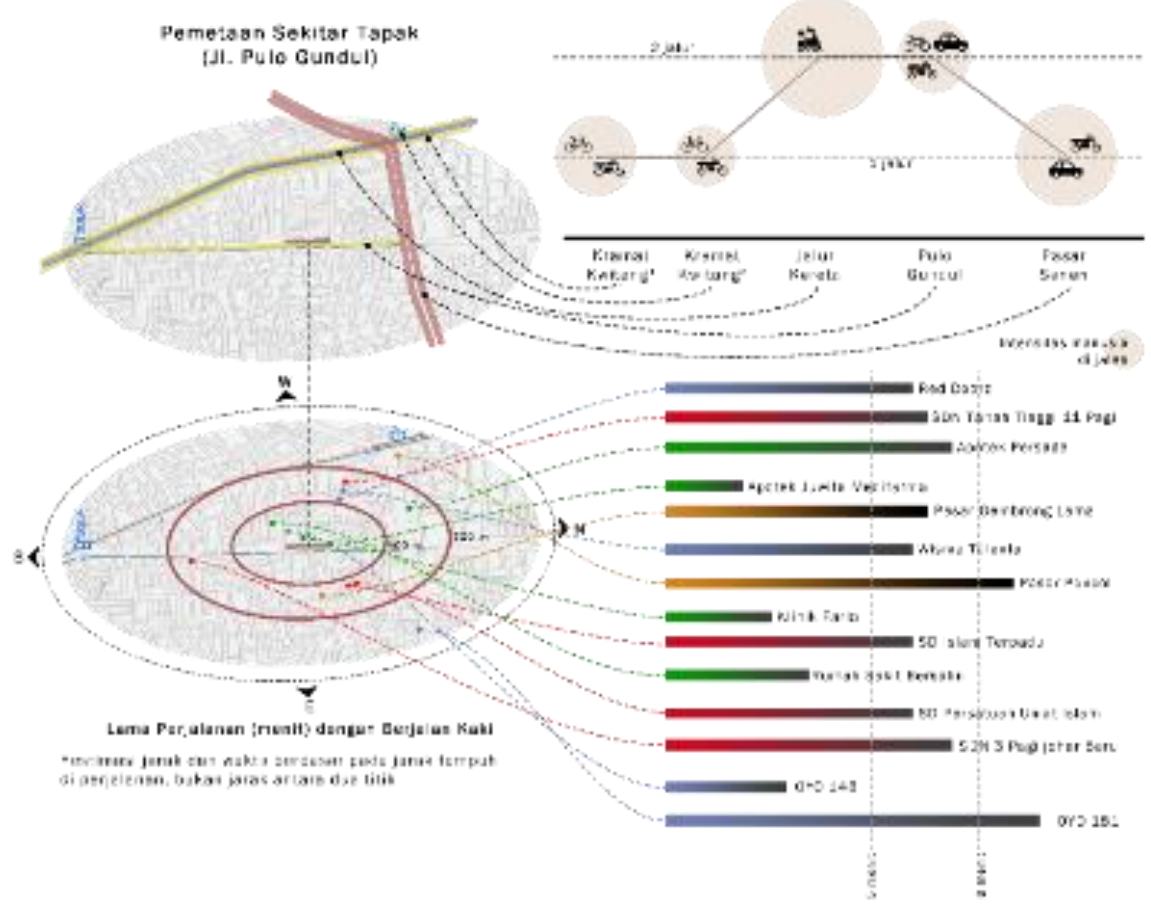

Gambar 6. Pemetaan Fasilitas di Sekitar Tapak Sumber: Analisis Penulis, 2021

Tapak perancangan seluas $3.489 \mathrm{~m}^{2}$ berada di Jl. Pulo Gundul, Kel. Tanah Tinggi, Kec. Johor Baru dengan zona campuran (C1). Dominasi fasum dan fasos memiliki potensi yang mendatangkan pengunjung. Dari pemetaan didapatkan pengunjung yang datang dapat dikategorikan menjadi 5 , yaitu komunitas aktivitas (seperti grup senam dan sepeda), masyarakat umum, turis non-lokal, murid SD terprogram ekstrakurikuler, serta kelompok siswa dan peneliti akademik. Kombinasi jenis pengunjung bermanfaat dalam penentuan ruang aktivitas dan stimulus psikologis yang sesuai. 


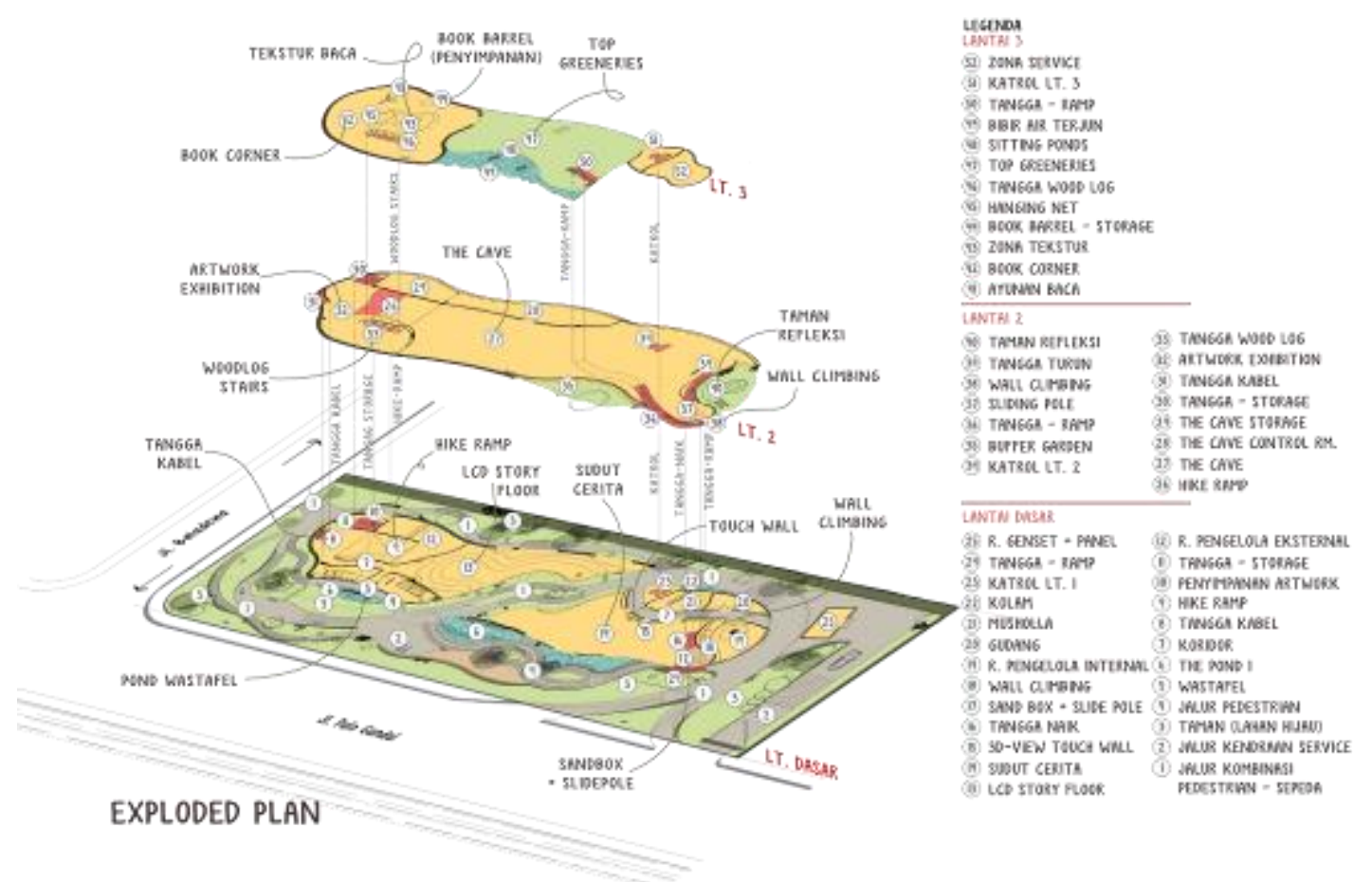

Gambar 7. Aksonometri Denah dan Akses Vertikal Sumber: Analisis Penulis, 2021

Penataan ruang disusun secara linier dan bersambung, di mana sudut akhir setiap ruang dibuat seakan memancing pengunjung untuk terus bereksplorasi ke ruang berikutnya, sehingga variasi aktivitas yang dilakukan lebih maksimal. Selain tangga pada umumnya, akses vertikal yang ditawarkan juga divariasikan dengan aktivitas yang mendorong gerak motorik. Hal ini dikarenakan rangsangan motorik mendorong seseorang untuk melakukan interaksi sosial.

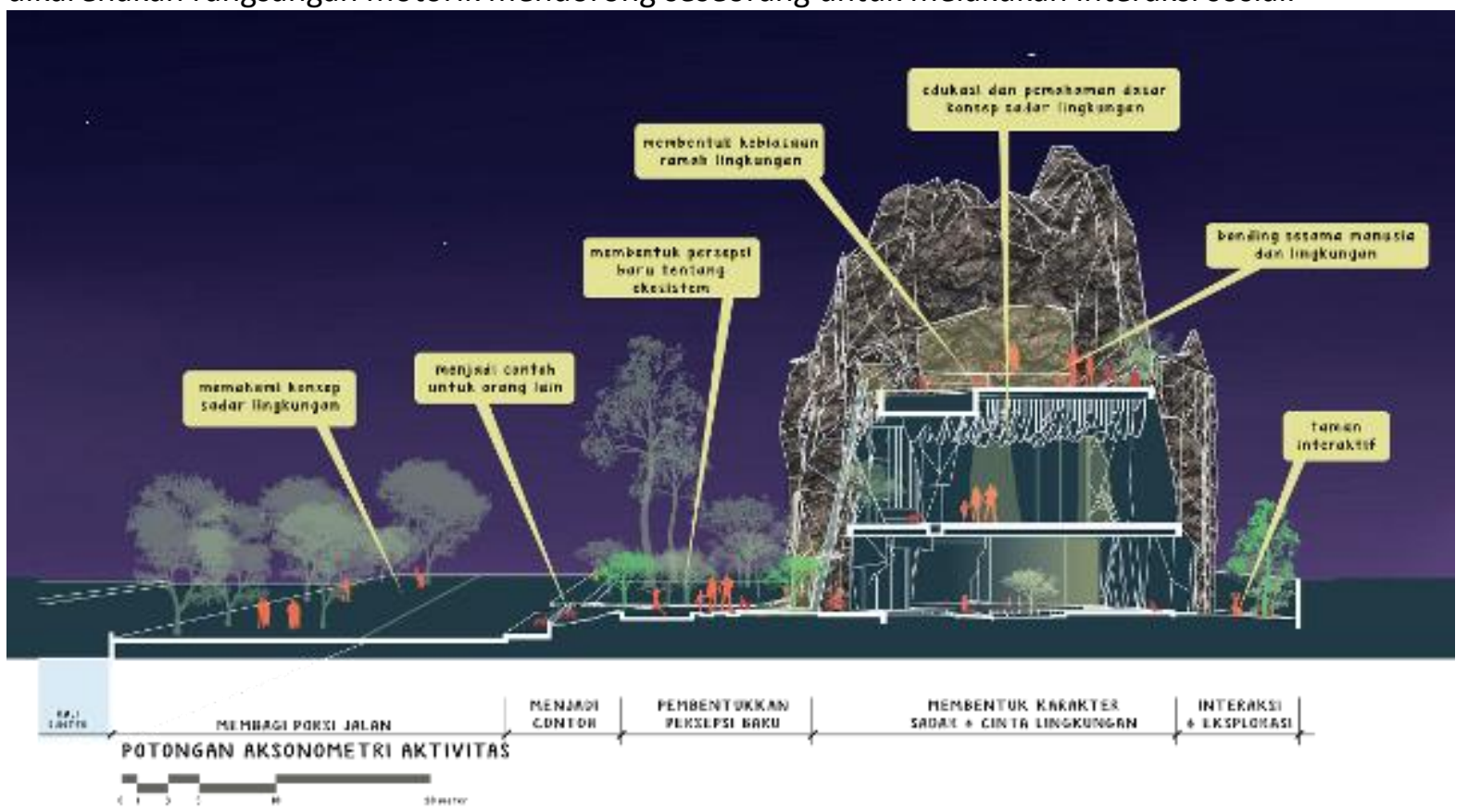

Gambar 8. Interaksi dan Manfaat Kegiatan

Sumber: Analisis Penulis, 2021

Setiap ruang dan aktivitas dalam tapak mengandung nilai-nilai ekologis dan menstimulus pikiran penggunanya, sehingga pengunjung menjadi tergerak dan terpengaruhi pada aktivitas-aktivitas 
berikutnya. Misalnya, pada taman interaktif, pengunjung dituntut untuk melakukan interaksi dengan yang lainnya, mulai dari memetik buah, bermain bersama di alat-alat permainan yang disediakan, dan mungkin meminta bantuan atau menolong pengunjung lain. Sirkulasi pengunjung dibuat linier dengan tujuan mengarahkan pengunjung dari satu ruang ke ruang lain secara menerus. Dengan demikian, kecenderungan untuk memasuki semua ruang dan terarah lebih tinggi.

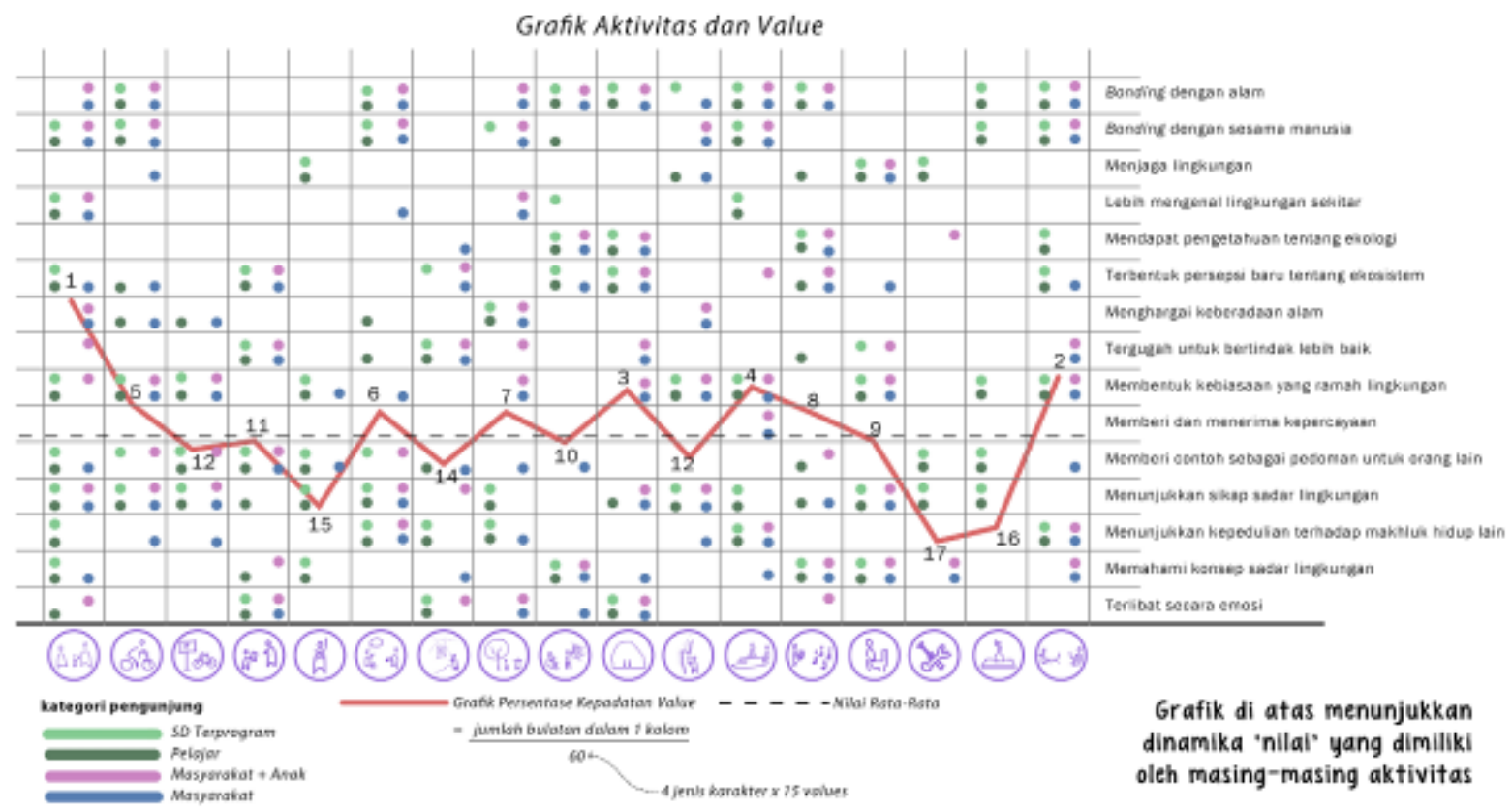

Gambar 9. Grafik Bobot Nilai Ekologis Aktivitas

Sumber: Analisis Penulis, 2021

Pemberian nilai-nilai ekologis bertujuan untuk memastikan agar setiap ruang memiliki unsur yang dapat mempengaruhi persepsi dan perilaku manusia, interaksi di dalamnya, serta wujud ruang yang ingin dicapai beserta kebutuhannya. Selain itu, nilai yang terkandung juga berfungsi sebagai parameter untuk mengukur tingkat kesadaran setiap pengunjung berdasarkan ruangruang yang telah dikunjunginya. Setiap titik (dots) mewakili satuan kategori pengunjung yang lebih berpotensi untuk mengikuti aktivitas tertentu (komponen horizontal) lalu mendapat/menyerap dampak dan nilai intrinsik yang ditanamkan dalam aktivitas tersebut (komponen vertikal). Akumulasi nilai dari titik-titik tersebut menunjukkan kecenderungan aktivitas tersebut untuk berpengaruh dalam diri seseorang yang ditunjukkan dalam grafik. Dengan demikian, didapat skala prioritas untuk perancangan aktivitas dan ruang geraknya. Selain itu, dinamika grafik memperlihatkan bahwa setiap aktivitas yang ditawarkan memiliki nilai-nilai ekologis yang sedikit-banyak akan berpengaruh pada setiap individu sebagai pengunjungnya. 

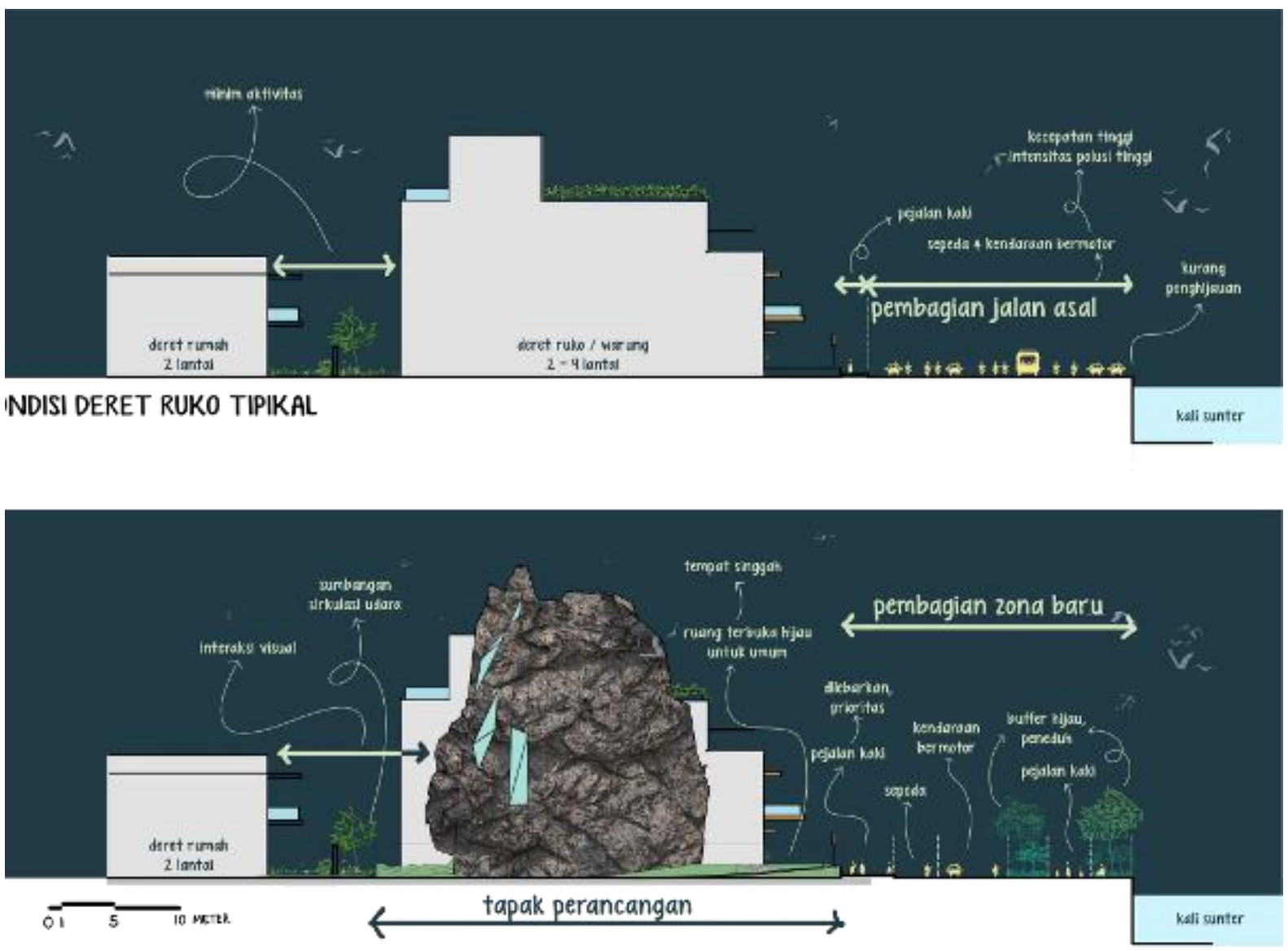

ILUSTRASI KEHADIRAN PROYEK

\section{KOMPARASI WAJAH SAMPING KIRI LINGKUNGAN}

Gambar 10. Visual Bangunan \& Lingkungan yang Sadar akan Keseimbangan Alam Sumber: Analisis Penulis, 2021

Beberapa perubahan dan penyesuaian yang dilakukan pada perancanagan dapat terlihat dari komparasi visual lingkungan. Sumbangan ruang hijau terbuka pada lingkungan diletakkan pada sisi-sisi batas tapak sebagai jembatan interaksi antara penduduk atau pengguna jalan dengan pengunjung bangunan. Area yang lebih luas secara tidak langsung mendorong individu untuk melihat lebih jauh, mengamati, lalu berkeinginan untuk terlibat di dalam ruang yang ada. Interaksi tersebut menunjukkan keramahan bangunan sebagai suatu wadah kegiatan yang hadir di tengah-tengah permukiman. Penghuni rumah tipe deret pada sisi belakang tapak dapat berkomunikasi secara visual dan audio dengan pengunjung bangunan (dari taman interaktif). Hal ini membuat masyarakat tidak merasa diabaikan sebagai penguhni yang sudah lebih dulu menempati wilayah tersebut. Sedangkan, pedestrian dan pengguna kendaraan non-bermotor dapat transit ke taman pada sisi depan bangunan, karena jalur yang disediakan aksesibel bagi umum.

Penggunaan jalan yang semula digabungkan antara kendaraan bermotor dan tidak dengan trotoar pada sisi lahan bangunan juga dirasa kurang cocok dengan lingkungan dan perancangan yang ada. Oleh sebab itu, usulan baru pembagian jalan memperlebar trotoar yang semula 2 meter menjadi 4,5 meter, dapat diakses oleh pengguna kursi roda. Jalur pedestrian ditambahkan di tepi Kali Sunter, sebagai respon terhadap penggunaan transportasi umum dan sistem TOD yang lebih dimaksimalkan, menimbang Jl. Pulo Gundul berada dalam jangkauan jalur bus dan 
kereta api. Jalur khusus sepeda sebanyak 2 lajur juga disediakan sebagai tanggapan terhadap kemungkinan transportasi sepeda yang semakin marak ke depannya.

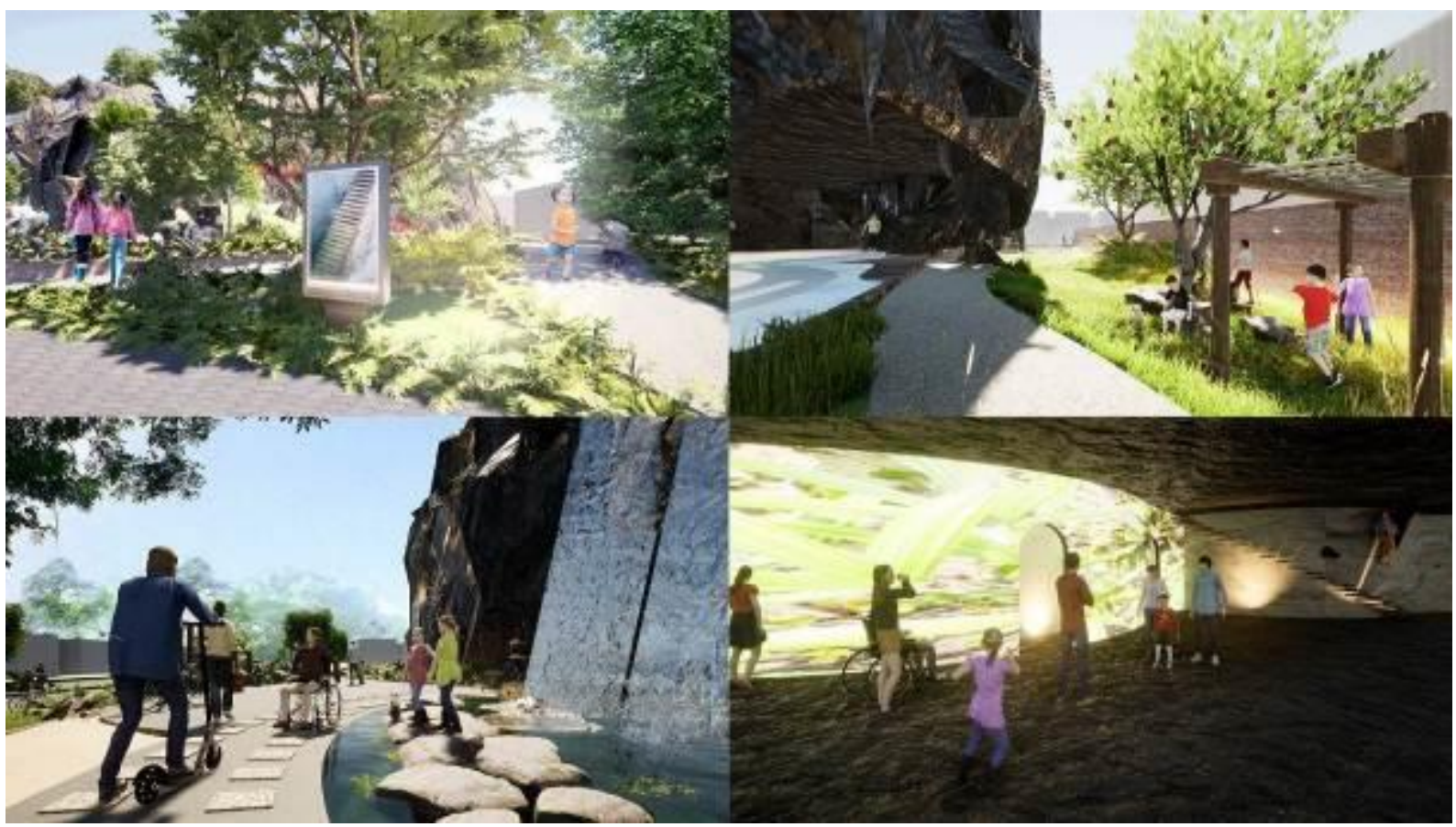

Gambar 11. Suasana dalam perancangan: (a) Akses Keluar-Masuk, (b) Taman Interaktif,

(c) Jalur Akses, (d) LCD Touch-Wall

Sumber: Analisis Penulis, 2021

Sensor dan monitor pada akses keluar-masuk tapak (Gambar 10. a) berfungsi untuk mendeteksi wajah pengunjung sebagai rekam jejak individual pengunjung. Sisi layar akan menampilkan cuplikan-cuplikan dari aktivitas/kejadian yang terjadi di dalam perancangan, baik itu positif maupun negatif dengan tetap menjaga privasi pelaku. Sistem ini bertujuan untuk menunjukkan kondisi riil atau nyata yang ada, sehingga mereka yang menontonnya dapat melakukan refleksi diri secara mandiri serta mengolah informasi yang diberikan berdasarkan norma atau kebenaran umum yang ada. Unit-unit serupa disebar di seluruh bagian perancangan sehingga pemantauan dapat dilakukan secara menyeluruh dan merata.

Area hijau terbuka pada sisi belakang tapak (Gambar 10. b) yang berbatasan dengan deret rumah merupakan taman interaktif, di mana pengunjung diarahkan untuk melakukan aktivitas fisik ringan, seperti memetik buah-buahan, menggantung dan memanjat di alat-alat permainan, serta saling berkomunikasi dan berinteraksi antarpengunjung. Sedangkan, jalur yang ada pada ruang luar (Gambar 10. c) tidak memisahkan jalur pedestrian, sepeda, kursi roda, skuter, dan sebagainya secara khusus dan spesifik. Tujuannya adalah untuk mengeluarkan sisi toleran yang ada dari setiap pengunjung. Ketika dua atau lebih jenis pengunjung bertemu atau berpapasan pada jalur yang sama, maka mereka dituntut untuk bereaksi/memberi respon dengan cepat dengan kecenderungan salah satunya akan mengalah. Perilaku tersebut apabila dilakukan secara berulang akan menjadi sebuah kebiasaan yang dapat diterapkan pada kondisi keseharian lainnya. Selain itu, bagi pengamat, mereka melihat bahwa hal demikian merupakan sebuah contoh yang baik.

Untuk membuka wawasan pengunjung terhadap situasi yang terjadi di berbagai wilayah, dinding LCD berfungsi untuk memperlihatkan kondisi alam di bagian lain, misalnya desa adat yang jarang 
diketahui gambarannya, kenampakkan alam, atau habitat yang dilindungi di wilayahnya. Dengan demikian, kita dapat membandingkan beberapa kondisi dan mencerna perbedaan yang ada di antaranya.

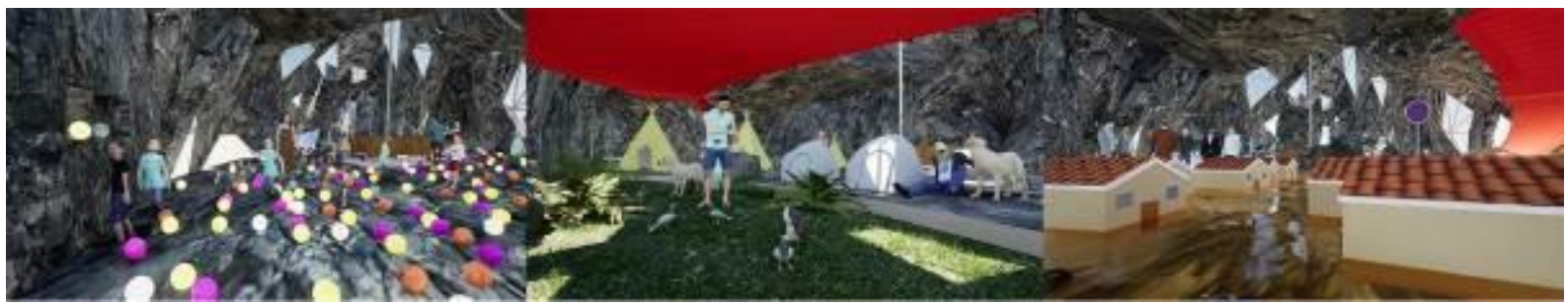

Gambar 12. Macam-Macam Suasana dalam The Cave: (a) Ball Experiment,

(b) Pet Camp, (c) Flood Experiment Sumber: Analisis Penulis, 2021

The Cave sebagai tempat aktivitas temporer memberikan pengalaman berbeda kepada pengunjung setiap 3 bulan. Eksperimen bola-bola limbah (Gambar 11. a) memberi stimulus untuk kerap menjaga lingkungan sekitarnya sebelum hal tersebut justru memberi dampak negatif pada dirinya sendiri. Objek bola juga memberi informasi mengenai jenis-jenis limbah yang dihasilkan manusia dalam kesehariannya. Dalam program kemah bersama hewan peliharaan (Gambar 11. b), pengunjung (penghuni sementara) diajak untuk melihat interaksi alamiah ketika hewan-hewan tersebut bertemu dengan hewan lainnya. Pada kondisi ini, manusia dituntut untuk mengikuti reaksi umum hewan dengan harapan dapat memperlakukan mereka dengan lebih baik, atau bahkan memutuskan untuk menyerahkan hewan-hewan peliharaannya ke animal shelter untuk dirawat dalam kelompok besar. Sedangkan, pada eksperimen banjir (Gambar 11. c), pengunjung diarahkan untuk membuang sampah di beberapa titik yang ternyata adalah bagian daripada miniatur sebuah permukiman. Sembari mengikuti alur perjalanan, pengunjung akan merasakan genangan air dan mendapatkan permukiman miniatur itu telah tergenang oleh banjir. Tujuan dari memberikan pengalaman langsung kepada pengunjung adalah untuk melekatkan memori, karena manusia memiliki kecenderungan untuk mengingat hal-hal tidak wajar/umum yang dialaminya.

Aktivitas-aktivitas tersebut akan terus berubah dan bergilir secara berkala, mengikuti proses perubahan pengunjungnya dan respon yang diberikan, sehingga tidak ada program tertentu yang tetap dalam The Cave. Dengan demikian, program aktivitas yang diadakan akan relevan dan tetap sesuai perkembangan yang terjadi, untuk mendorong perubahan yang membaik setiap kalinya.

\section{KESIMPULAN DAN SARAN Kesimpulan}

Kemajuan teknologi dan kemudahan sistem kehidupan membuat manusia bertindak semakin acuh terhadap lingkungan sekitarnya dan tidak menganggapnya sebagai sebuah tanggungjawab. Berdasarkan studi dan perancangan yang telah dilakukan, dapat ditarik kesimpulan bahwa persepsi yang sudah membekas dalam diri manusia dapat dialihkan menjadi persepsi baru, terlebih lagi bila input baru tersebut diberikan secara rutin dan konsisten. Tidak terkecuali pandangan tentang pentingnya untuk mengembangkan perilaku yang sadar lingkungan, dapat ditanamkan secara terus-menerus khususnya sejak kecil agar menjadi pola kebiasaan.

Proyek ini hadir di tengah kehidupan masyarakat sebagai contoh dari respon bangunan yang 
memperhatikan kepentingan semua unsur di lingkungan sekitarnya, mulai dari alam sebagai penyedia tempat, makhluk hidup sebagai penghuni, benda-benda ciptaan sebagai pelengkap dan pemenuh kebutuhan, serta dampak dan akibat yang ditimbulkan dari interaksi ketiganya. Program aktivitas yang ada di dalamnya juga bertujuan untuk mendorong sifat toleran dan kepekaan terhadap kejadian-kejadian yang ada di sekitarnya, khususnya yang bersifat alamiah sebagai hal yang tidak dapat dihindari oleh setiap dari kita. Mendatangkan berbagai macam kelompok manusia, hewan, dan tumbuhan berfungsi sebagai langkah awal dalam menunjukkan normalnya kemajemukan yang ada, dan setiap keberagaman tersebut mendorong interaksi yang unik dan khas.

\section{Saran}

Dengan situasi yang terjadi saat ini, menjadi penting untuk mengedukasi masyarakat tentang sadar lingkungan, langkah-langkah, dan keterkaitan hal sehari-hari di dalamnya. Pendekatan tersebut tentunya diharapkan agar tidak terkesan memaksa dan proses berjalan secara alamiah. Oleh sebab itu, penulis harap fokus penelitian atau perancangan serupa semakin ditingkatkan baik dengan menggunakan metode dan teori yang serupa maupun dengan teknik relevan lainnya. Selain itu, implementasi konsep sadar lingkungan dapat diterapkan ke jangkauan masyarakat dan program sekolah yang lebih luas, termasuk juga pada ruang-ruang terbuka hijau yang menyebar.

\section{REFERENSI}

Burnie, D. (2005). Bengkel Ilmu: Ekologi. Jakarta: Erlangga.

Cañas, P. M. (2019, April 8). The understanding of the body and movement in Merleau-Ponty1. doi:10.1590/0101-3173

CapeSpace. (n.d.). How the 21/90 rule helps you build good habits and a better life. Retrieved from CapeSpace: https://www.capespace.com/how-the-21-90-rule-helps-you-buildgood-habits-and-a-better-life/

Hudha, A. M., Husamah, \& Rahardjanto, A. (2018). Etika Lingkungan (Teori dan Praktik Pembelajarannya) (Cetakan Pertama ed.). Malang, Indonesia: Universitas Muhammadiyah Malang.

Prochaska, J. O. (1982). Transtheoretical therapy: Toward a more integrative model of change. Psychotherapy: Theory, Research \& Practice, 19(3), 276-288.

Velasquez, M., Andre, C., Shanks, T., Meyer, M. J., \& S.J. (2010, January 1). What is Ethics? Retrieved from https://www.scu.edu/ethics/ethics-resources/ethical-decisionmaking/what-is-ethics/

Watling, T. (2011). Ecological Imaginations in the World Religions. Continuum.

Wilber, K. (1997). An Integral Theory of Consciousness. Journal of Consciousness Studies(4), 7192. Retrieved February 17, 2020, from http://www.newdualism.org/papers/K.Wilber/Wilber-JCS1997.pdf 